\title{
Plasminogen activator inhibitor 1 and Antipain preserve acrosome integrity of bovine spermatozoa during cryopreservation
}

\author{
[Inibidor do ativador do plasminogênio 1 e antipaína preservam a integridade \\ do acrossoma de espermatozoides bovinos durante a criopreservação] \\ M.A. Castelo Branco ${ }^{1}$, Y.N.T.C. Castelo Branco ${ }^{1}$, F.J. Moraes Junior ${ }^{2}$, F.N. Barros ${ }^{1}$, \\ F.P.S. Barçante ${ }^{1}$, G.M.C. Carvalho ${ }^{3}$, L.S. Melo Evangelista ${ }^{1}$, A.L. Abreu-Silva ${ }^{4}$, \\ M.A. Sousa Filho ${ }^{1}$, J.A.T. Souza ${ }^{1}$ \\ ${ }^{1}$ Universidade Federal do Piauí - Campus Socopo - UFPI - Teresina, PI \\ ${ }^{2}$ Aluno de pós-graduação - UEMA - PNPD/CAPES - São Luís, MA \\ ${ }^{3}$ Empresa Brasileira de Pesquisa Agropecuária - EMBRAPA - Teresina, PI \\ ${ }^{4}$ Universidade Estadual do Maranhão - UEMA - São Luiz, MA
}

\begin{abstract}
Seminal plasma contains serine proteases and serine protease inhibitor, which are involved in mammalian fertilization, and the inhibitors can be applied to prevent cold-induced sperm capacitation. The effects of different concentrations of two serine protease inhibitors were analyzed, Plasminogen activator inhibitor 1

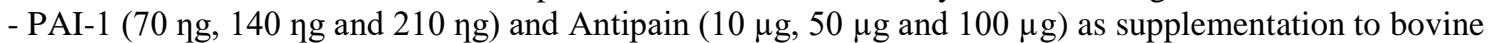
semen cryopreservation extender. The effects of the inhibitors on the sperm parameters (sperm kinetics CASA, acrosome integrity, plasma membrane integrity, mitochondrial membrane potential, sperm defects and acrosome reaction rate) were evaluated in the post-thaw semen. Cryopreservation of sperm with Antipain decreased post-thaw kinetic parameters of MP, VSL, LIN, SRT and the percentage of hyperactivated sperm while PAI-1 (210 ๆg) decreased VSL and LIN. Antipain and PAI-1 had no effect on the integrity parameters of the plasma membrane, mitochondrial membrane potential and sperm defects. Sperm cryopreserved in the presence of Antipain and PAI-1 (70 and 140 ng) preserved acrosome integrity, as they were able to complete the in vitro acrosome reaction. In conclusion, the serine protease inhibitors, Antipain and PAI-1 (70 and 140ng) are able to preserve the acrosome integrity of cryopreserved bovine sperm.
\end{abstract}

Keywords: Curraleiro Pé-Duro, fertility, seminal evaluation, serine protease inhibitors, sperm cryopreservation

\section{RESUMO}

A criopreservação é parcialmente prejudicial à fertilidade do sêmen de bovinos e induz mudanças semelhantes à capacitação em espermatozoides. O plasma seminal contém serina-proteases e inibidores de serina-proteases que estão envolvidos na fertilização de mamíferos, e os inibidores podem ser aplicados para evitar uma capacitação espermática induzida pelo frio. Analisaram-se os efeitos de diferentes concentrações de dois inibidores de serina-proteases, inibidor do ativador do plasminogênio 1

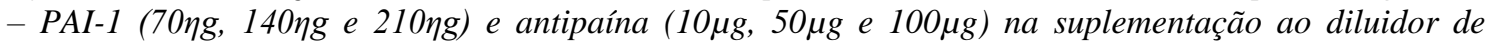
criopreservação de sêmen bovino. Trinta e seis ejaculados de quatro bovinos Curraleiro Pé-Duro foram usados para criopreservação. Os efeitos dos inibidores sobre os parâmetros dos espermatozoides (cinética espermática - CASA, integridade acrossomal, integridade da membrana plasmática, potencial de membrana mitocondrial, defeitos espermáticos e taxa de reação acrossomal) foram avaliados no sêmen pós-descongelamento. A criopreservação de espermatozoides com antipaína diminuiu os parâmetros cinéticos pós-descongelamento de MP, VSL, LIN, SRT e a porcentagem de espermatozoides

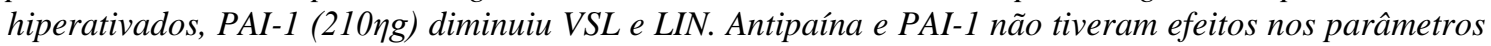

Recebido em 16 de outubro de 2016

Aceito em 23 de novembro de 2016

E-mail: marlon704@gmail.com 
de integridade da membrana plasmática, no potencial de membrana mitocondrial e nos defeitos

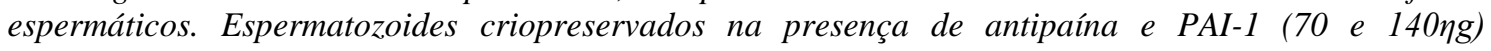
preservaram a integridade acrossomal, assim como foram capazes de completar a reação acrossômica in

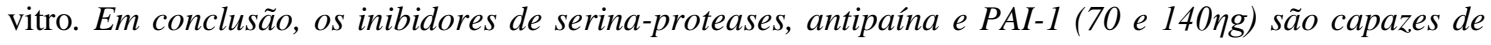
preservar a integridade acrossomal de espermatozoides criopreservados de bovinos.

Palavras-chave: Curraleiro Pé-Duro, fertilidade, avaliação seminal, inibidores de serino proteases, criopreservação espermática

\section{INTRODUCTION}

Over the last decades, bovine semen cryopreservation has been used to preserve genetic material from breeds at risk of extinction and to propagate animals with superior genetic characteristics by artificial insemination (AI) (Gurupriya et al., 2014). However, cryopreservation is partially damaging to mammalian sperm, it induces thermal and osmotic shock, oxidative stress and causes changes in the plasma membrane lipid composition, making it more reactive to the postthaw environment (Watson, 2000) and causes physiological changes similar to sperm capacitation in bovines (Miah et al., 2011), pigs (Green and Watson, 2001) and horses (Thomas et al., 2006), which is known as cryocapacitation (Thomas et al., 2006; Reddy et al., 2010). Some changes observed in in vivo sperm capacitation are similar to cryo-capacitation and include an increase in plasma membrane permeability, intracellular increase in calcium ion concentrations $(\mathrm{Ca} 2+)$ and cyclic adenosine monophosphate (cAMP) and tyrosine phosphorylation (Pommer and Meyers, 2002; Kumar and Atreja, 2011; Singh et al., 2012). In response to these changes, there is destabilization of proteins from the serine protease family present both in the acrosome and the sperm membrane (Cesari et al., 2010), leading to exocytosis of hyaluronidase and acrosin, which are important enzymes that digest the zona pellucida matrix, compromising the penetration of spermatozoa into the oocyte (Adham et al., 1997).

For fertilization to occur in mammals, a successful conclusion is needed of a series of steps in an obligatory order (Primakoff and Myles, 2002). Previous studies have shown that sperm cell, oocyte and their cumulus cells, contain and/or segregate several proteases (Tulsiani et al., 1998; Iwamoto et al., 1999; Shimada et al., 2004; Burkart et al., 2012).
The serine protease family enzymes play a key role in many biological processes, as well as in modulation of cellular and extracellular proteins (Beynon and Bond, 2001). They have this nomenclature because of the serine residue present at the active enzyme OR enzyme activity site, it is the largest proteases family, based on current knowledge, involved in the fertilization process of gametes from mammalian as well as non-mammalian species (Sawada et al., 1984; Yanagimachi, 1994). Serine protease activity contributes to regulating spermatozoa penetration in bovine oocytes mediated by release of tissue plasminogen activator (tPA) of the oocyte and activation of plasminogen to plasmin by serine protease enzymes (Rekkas et al., 2002). Recent studies describe how the plasminogen-plasmin system may contribute to the regulation of the spermatozoa penetration during fertilization in mammals (Coy et al., 2012; Mondéjar et al., 2012).

Plasminogen activator inhibitor, type 1 (PAI-1), belongs to the family I4 (SERPINS), the main plasminogen activator inhibitor (PA). PAI-1 is a single chain glycoprotein with 50,000 $\mathrm{Kd}$ molecular weight, it has 379 amino acids and contains $13 \%$ carbohydrate, it lacks cysteine residues but contains multiple residue methionine, which may explain its susceptibility to irreversible inactivation by oxidizing agents. The reactive center of the inhibitor (Arg 346-Met 347 ) is contained within the "region of the deformed loop" exposed at the carboxy-terminus of the molecule and serves as a pseudo-substrate to the target serine protease (Nar et al., 2000).

Antipain is another important serine protease inhibitor, it is an isolated oligopeptide from actinomycetes belonging to the family I1 (Kazal) and is used in biochemical research as a protease inhibitor similar to trypsin. It was crystallized in complex with wheat carboxypeptidase and oligopeptidase B, Leishmania major, in both 
cases, the dorsal carbonyl of Antipain arginine forms a covalent bond with the active site, inhibiting reversibly the serine proteases (Umezawa et al., 1972).

Serine proteases are involved in various aspects of the interaction of the gametes in mammals; these characteristics make them interesting candidates for further studies on how serine protease inhibitors may affect bovine fertilization. Overall, the inhibitors are designed to bind to the protease active site and interfere with its catalytic mechanism.

There is no evidence and studies on the effects of plasminogen activator inhibitor 1 and Antipain in sperm cryopreservation. Therefore, this study investigated the effects of serine protease inhibitor PAI-1 (plasminogen activator inhibitor 1) and Antipain in sperm cryopreservation of Curraleiro Pé-Duro bulls on important parameters of sperm quality: plasma membrane integrity, mitochondrial membrane potential, acrosome integrity, sperm kinetics, acrosome reaction rate, and sperm morphology.

\section{MATERIALS AND METHODS}

All procedures performed with the animals were in accordance with the European legislation for animal experimentation (Directive 2010/63 / EU) and with the Brazilian legislation on animal research (Law 11,794, October 8, 2008). The procedure described in the present article was approved by the Commission of Ethics in the Use of Animals (CEUA) of the Federal University of Piauí (UFPI) under Protocol $\mathrm{N}^{\circ}$ 005/14.

Serine protease inhibitors, Antipain, and plasminogen activator inhibitor 1 (PAI-1) and all other chemicals were purchased from SigmaAldrich® (St. Louis, MO, USA).

The Tris-Egg yolk extender consisting of $3.605 \mathrm{~g}$ Tris, $2.024 \mathrm{~g}$ citric acid, $1,488 \mathrm{~g}$ fructose, $25 \mathrm{mg}$ gentamicin, 50,000IU penicillin, $100 \mathrm{~mL}$ distilled water, $20 \%$ egg yolk and 5\% glycerol, with $\sim 350 \mathrm{mOsm}$ osmolality and $\mathrm{pH} 6.8$, was used to dilute and freeze the semen. Seven different experimental extenders were prepared as follows: Control (0ng), 70ng, 140ng and 210ng of plasminogen activator inhibitor 1 (PAI-1); and
Antipain at $10 \mu \mathrm{g}, \quad 50 \mu \mathrm{g}$ and $100 \mu \mathrm{g}$ concentrations added to Tris-Egg yolk extender.

Four Curraleiro Pé-Duro breed bulls were used from the Brazilian Enterprise for Agricultural Research - EMBRAPA North Environment (Meio Norte) located in the city of Teresina, Piauí, Brasil $\left(05^{\circ} 05^{\prime} 21^{\prime \prime}\right.$ latitude south and $42^{\circ}$ $48^{\prime} 07^{\prime \prime}$ longitude west), average age 5 years, weighing between 310 and $365 \mathrm{~kg}$ and with $3-4$ body condition score (scale 1 to 5 ). The bulls had a history of proven fertility and were assessed for general health, integrity of the reproductive organs and sperm quality. During the experiment, the bulls were kept under an extensive system, with free access to paddocks of Panicum maximum, water and mineral salt.

Semen samples were collected once a week for nine weeks, totaling 36 ejaculates, via electroejaculation (Biocon®, Uberaba, Minas Gerais, Brasil) using a $15 \mathrm{~mL}$ graduated sterile test-tube correctly protected with a sheet of aluminium/aluminum if publishing in the USA paper to prevent exposing the semen to light. The ejaculates were transported in an insulated box at $37^{\circ} \mathrm{C}$ to the laboratory for later evaluation. Immediately after arriving at the laboratory the semen samples from each animal were placed in a water bath at $37^{\circ} \mathrm{C}$ and assessed separately for colour, appearance, volume, total motility and force of spermatozoa motion (vigour), under a phase contrast microscope (Olympus Optical Co. Ltd., Tokyo, Japan), following the Brazilian College of Animal Reproduction (CBRA, 2013). The sperm concentration was obtained in a Neubauer chamber at 1:200 dilution in sodium citrate solution in formaldehyde at $4 \%$. The wet chamber method was used to analyse sperm morphology following the Brazilian College of Animal Reproduction (CBRA 2013). Only ejaculates with total motility $\geq 80 \%$; vigour $\geq 3$; sperm concentration $\geq 3.5$ X 109 spermatozoa $/ \mathrm{mL}$ and sperm pathologies $\leq 20 \%$ were used in the present study. When approved, samples of the four ejaculates were mixed to form a pool to increase the semen volume and eliminate variability among the sample studied. Shortly after forming the pool, it was divided into 10 aliquots, kept at $37^{\circ} \mathrm{C}$ in a water bath before dilution in the experimental extenders.

Six aliquots of previously assessed and approved semen were diluted in Tris-Egg yolk culture 
medium $\left(37^{\circ} \mathrm{C}\right)$ containing PAI-1 (70ng, 140ng

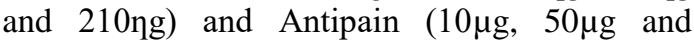
$100 \mu \mathrm{g})$, while one aliquot without any supplementation was kept as the control. The diluted semen was placed on $0.5 \mathrm{~mL}$ straws $(50 \mathrm{X}$ 106 viable spermatozoa per straws) and frozen in a TK 3000®machine (TK Ltda, Uberaba, Brazil), on the fast freezing curve $\left(-0.25^{\circ} \mathrm{C} / \mathrm{min}\right.$, from $25^{\circ} \mathrm{C}$ to $5^{\circ} \mathrm{C}$ and $-20^{\circ} \mathrm{C} / \mathrm{min}$, from $5^{\circ} \mathrm{C}$ to $-120^{\circ} \mathrm{C}$ ) and after reaching $-120^{\circ} \mathrm{C}$ the plates were plunged in liquid nitrogen $\left(-196^{\circ} \mathrm{C}\right)$ and stored in a cryopreservation tank. The equilibrium time at $5^{\circ} \mathrm{C}$ was 60 minutes. After 30 days in storage, the semen samples were thawed in a water bath at $37^{\circ} \mathrm{C}$ for 30 seconds and assessed for plasma membrane integrity, acrosome integrity, mitochondrial membrane potential, sperm kinetics, acrosome reaction test and sperm morphology.

To assess the plasma membrane integrity, the double staining method was used with carboxyl fluorescein diacetate (DCF; Sigma-Aldrich ${ }^{\circledR}$, St. Louis, MO, USA) and propidium iodide (IP; Sigma-Aldrich ${ }^{\circledR}$, St. Louis, MO, USA), modified by Coleto et al. (2002). Aliquots (50 $\mu \mathrm{L})$ of post-thawed semen were diluted in $150 \mu \mathrm{l}$ Tris $(3,605 \mathrm{~g}$ Tris, $2,024 \mathrm{~g}$ citric acid, 1,488g fructose, $100 \mathrm{~mL}$ distilled water) containing $5 \mu \mathrm{L}$ DCF $(0.46 \mathrm{mg} / \mathrm{mL}$ in DMSO) and $20 \mu \mathrm{L}$ IP $(0.5 \mathrm{mg} / \mathrm{mL}$ in PBS $)$ and incubated for 10 minutes at $38^{\circ} \mathrm{C}$. A total of 200 spermatozoa was assessed under epifluorescence microscopy (Olympus Optical Co., Ltda., Tokyo, Japan) with 400X magnification, using DBP 580-630nm emission filter and DBP 485/20nm excitation. The sperm were classified as with intact membrane when they were stained green, and damaged membrane when stained red.

The acrosome integrity was assessed using fluorescein isothiocyanate stain in conjunction with Peanut agglutinin (FITC-PNA; SigmaAldrich ${ }^{\circledR}$, St Louis, MO, USA), according to the technique described by Roth et al. (1998). One $20 \mu \mathrm{L}$ aliquot of the FITC-PNA stock solution $(1 \mathrm{mg} / \mathrm{mL})$ was thawed and added to $480 \mu \mathrm{L}$ buffered phosphate solution (PBS) to obtain $100 \mu \mathrm{g} / \mathrm{mL}$ final concentration. Aliquots $(20 \mu \mathrm{l})$ of this solution were placed on smear slides containing spermatozoa, which were incubated for 20 minutes in a wet chamber at $4^{\circ} \mathrm{C}$, without light. After incubation, these slides were rinsed twice in chilled $\left(4^{\circ} \mathrm{C}\right)$ PBS and placed to dry in the dark. Immediately before the assessment, $5 \mu \mathrm{l}$ UCD mounting culture medium $(4.5 \mathrm{~mL}$ glycerol, $0.5 \mathrm{~mL}$ PBS, $5 \mathrm{mg}$ sodium azide and $5 \mathrm{mg} \mathrm{p}-$ phenylenodiamine) were placed on the slide and covered with a slide cover. Two hundred spermatozoa were assessed per slide, with 1000x magnification under immersion oil, in an epifluorescence microscope (Olympus Optical Co. Ltd., Tokyo, Japan), using an LP 515nm emission filter and BP 450-490nm for excitation. The spermatozoa were classified as intact acrosome carriers when the acrosome region was stained with green fluorescence, or as a reacted acrosome, when they presented a fluorescent green band in the equatorial region of the sperm head or did not present green fluorescence in any of the head region.

The mitochondrial function was determined by using a JC-1 lipophilic cationic fluorochrome (Guthrie and Welch, 2006). For this, 50 $\mu 1$ aliquots of post-thawed semen were diluted in $150 \mu \mathrm{L}$ Tris containing $5 \mu \mathrm{L} \mathrm{JC-1}(0.15 \mathrm{mM}$ in DMSO) and incubated for 10 minutes at $38^{\circ} \mathrm{C}$. A total of 200 spermatozoa were assessed under epifluorescence microscopy (Olympus Optical Co., Ltd., Tokyo, Japan) with 1000x magnification and immersion oil, using LP $515 \mathrm{~nm}$ emission filter and BP 450-490nm for excitation. The cells stained orange were classified with high mitochondrial membrane potential and those stained green were classified with low potential.

The sperm kinetics were assessed by a computerassisted sperm analysis system (CASA). CASA is a phase contrast optical microscopy system (Nikon тм H5505, Eclipse 50i, Japan), with strobic illumination and a hot phase at $37^{\circ} \mathrm{C}$, a video camera (Basler Vision Tecnologie TM A312FC, Ahrensburg, Germany) and a PC with the Classe TM sperm analysis software (Microptics, SL, version 3.2.0, Barcelona, Spain). The sperm kinetic variables were evaluated after diluting the sample in $2.94 \%$ sodium citrate $(\mathrm{v} / \mathrm{v})$ and then incubated in a water bath at $37^{\circ} \mathrm{C}$ for $5 \mathrm{~min}$. The following variables were assessed: total motility (MT-\%), progressive motility (MOP - $\mu \mathrm{m} / \mathrm{s})$, curvilinear velocity (VCL - $\mu \mathrm{m} / \mathrm{s})$, straight line velocity (VSL - $\mu \mathrm{m} / \mathrm{s}$ ), average journey velocity (VAP$\mu \mathrm{m} / \mathrm{s}$ ), linearity (LIN - \%), retilinearity (STR-\%), head side displacement (ALH - $\mu \mathrm{m})$, Wobble (WOB - \%), cross beat frequency (BCF-Hz) and 
Hyperactivation (HIPER-\%), for each analyzed spermatozoa.

The frozen semen, supplemented with different concentrations of serine protease inhibitors, was thawed in water at $37^{\circ} \mathrm{C}$ for 30 seconds and centrifuged (Centrifuge Labofuge 300 Heraeus) in percoll gradient $(90-45 \%)$ at $1200 \times \mathrm{g}$ for 10 minutes and subsequently washed by centrifuging at $1200 \times \mathrm{g}$ with sp-Talp medium for 3 minutes. An average of $3 \times 106$ motile spermatozoa were incubated in $1 \mathrm{ml}$ of IVF medium for each treatment, adding up, 100mg of heparin. Semen with heparin was maintained in Thermo Scientific (Revco) what is the name of the apparatus? at $39^{\circ} \mathrm{C}$ and $5 \% \mathrm{CO} 2$ for 6 hours. In the intervals (0 to 6 hours), sub-samples were taken and destined for staining with FITC-PNA as described earlier to evaluate the acrosome membrane integrity. The acrosome reaction rate (\% RA) was calculated with the following formula: (Percentage of spermatozoa that suffered acrosome reaction after 6 hours of stimulation - percentage in the minutes "0") / $(100 \%$ - percentage in 0 minutes) $\times 100$ (Murase et al., 2001).

A $200 \mu 1$ aliquot of thawed sperm was placed in a tube with $500 \mu$ l sodium citrate solution with $4 \%$ formoldehyde, sperm morphology was performed by the wet chamber technique, which consists of placing a 10 aliquot of semen with sodium citrate with $4 \%$ formoldehyde on a slide and covering with a cover slip. A total of 200 spermatozoa as analyzed per slide and the defects were classified as major, minor, and total, according Bloom (Bloom, 1973).

A randomized block experimental design was used with seven treatments: control, PAI-1 (70), PAI-1 (140), PAI-1 (210), Antipain (10), Antipain (50) and Antipain (100), in nine collections. The variables studied (plasma membrane integrity, mitochondrial membrane potential, acrosome integrity, sperm kinetics, acrosome reaction test and morphology) were subjected to analysis of variance (ANOVA). The means were compared by the parametric StudentNewman-Keuls test (SNK) at $5 \%$ probability. The analyses were performed using the Statistical Analysis System program (SAS Institute Inc., 2013).

\section{RESULTS}

The kinetic parameters after thawing the spermatozoa cryopreserved under different concentrations of serine protease inhibitors are shown in Table 1. The spermatozoa cryopreserved under extender containing different concentrations of Antipain showed lower values $(\mathrm{P}<0.05)$ of MP, VSL, LIN, SRT and hyperactivity when compared to the control; the other spermatic kinetic parameters did not differ statistically from the control when cryopreserved with Antipain. The plasminogen activator inhibitor 1 (PAI-1) at a concentration of 210 ng had a negative effect on the VSL and LIN parameters. The other parameters remained statistically $(\mathrm{P}>0.05)$ unchanged compared to the control.

Table 1. Kinetic parameters Post-thawing of Curraleiro Pé-Duro bovine semen cryopreserved at different concentrations of serine proteases inhibitors Antipain (10, 50 e $100 \mu \mathrm{g}$ ) and inhibitor plasminogen activator 1 - PAI 1 (70, 140 e 210 ng)

\begin{tabular}{|c|c|c|c|c|c|c|c|c|c|c|}
\hline \multirow[b]{2}{*}{ Treatments } & \multicolumn{10}{|c|}{ Kinetic parameters } \\
\hline & MT & MP & VCL & VSL & VAP & LIN & SRT & $\overline{\mathrm{ALH}}$ & $\mathrm{BCF}$ & HIPER. \\
\hline Control & $53.7 \pm 10.7$ & $34.8 \pm 16.2^{\mathrm{a}}$ & $87.5 \pm 10.1$ & $51.1 \pm 14.8 \mathrm{a}$ & $62.1 \pm 13.2$ & $57.7 \pm 9.4 \mathrm{a}$ & $81.2 \pm 6.4 \mathrm{a}$ & $3.1 \pm 0.3$ & $10.5 \pm 0.6$ & $12.4 \pm 3.2 \mathrm{a}$ \\
\hline PAI-1(140) & $50.3 \pm 8.2$ & $26.8 \pm 8.4 \mathrm{ab}$ & $78.9 \pm 14.5$ & $38.8 \pm 9.3 \mathrm{ab}$ & $51.8 \pm 10.6$ & $48.9 \pm 5.1 \mathrm{ab}$ & $74.5 \pm 3.3 \mathrm{ab}$ & $3.1 \pm 0.3$ & $11.3 \pm 0.6$ & $10.2 \pm 5.3 \mathrm{a}$ \\
\hline PAI-1(210) & $47.0 \pm 13.0$ & $21.3 \pm 7.3 \mathrm{ab}$ & $75.8 \pm 15.8$ & $33.9 \pm 10.2 b$ & $45.5 \pm 11.7$ & $44.1 \pm 5.8 \mathrm{~b}$ & $73.8 \pm 5.1 \mathrm{ab}$ & $3.5 \pm 0.4$ & $11.3 \pm 1.0$ & $9.1 \pm 4.2 \mathrm{a}$ \\
\hline Antipain 100 & $28.9 \pm 11.3$ & $13.5 \pm 9.5 b$ & $68.3 \pm 20.9$ & $31.4 \pm 13.8 \mathrm{~b}$ & $43.2 \pm 16.1$ & $44.6 \pm 6.4 \mathrm{~b}$ & $71.3 \pm 4.9 \mathrm{~b}$ & $2.9 \pm 0.2$ & $11.7 \pm 1.5$ & $5.1 \pm 5.0 \mathrm{~b}$ \\
\hline
\end{tabular}

Values are expressed as average \pm standard deviation (SD)

MT - Total motility; MP - Progressive motility; VCL - curvilinear speed; VSL - Straight-line speed; VAP - Average speed path; LIN - Linearity; STR - Straightness; WOB - Oscillation; ALH - Lateral displacement amplitude of the head; BCF - Frequency of tail beat, and HYPER - Hyperactivation.

Mean values with different lowercase letters $(\mathrm{a}$ and $\mathrm{b})$ in the same column indicate significant differences $(\mathrm{P}<0.05)$ by the SNK test. 
There was no significant difference $(\mathrm{P}>0.05)$, after thawing, in the plasma membrane integrity (\% IMP), mitochondrial membrane potential (\% PMM) (Figures 1 and 2) and morphology
(Table 2) of semen samples cryopreserved at different concentrations of serine protease inhibitors (PAI 1 and Antipain).

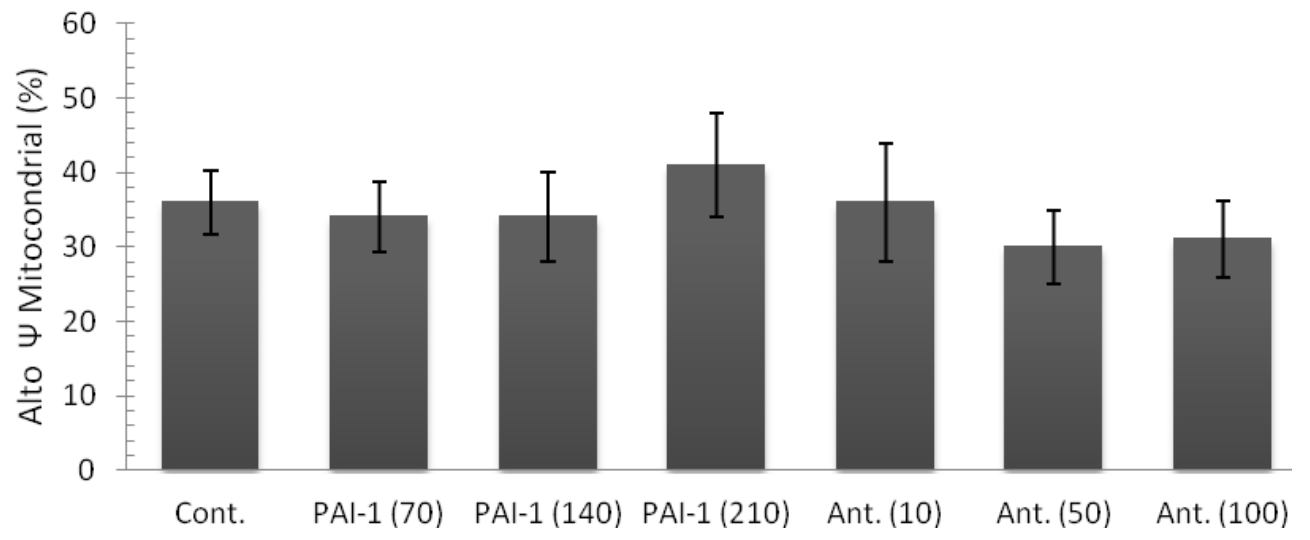

Figure 1. Post-thawing mitochondrial membrane potential of Curraleiro Pé-Duro bovine semen cryopreserved at different concentrations of serine proteases inhibitors Antipain (10, 50 e $100 \mu \mathrm{g})$ and inhibitor plasminogen activator 1 - PAI 1 (70, 140 e 210ng). Different letters in the column indicate significant differences $(\mathrm{P}<0.05)$.

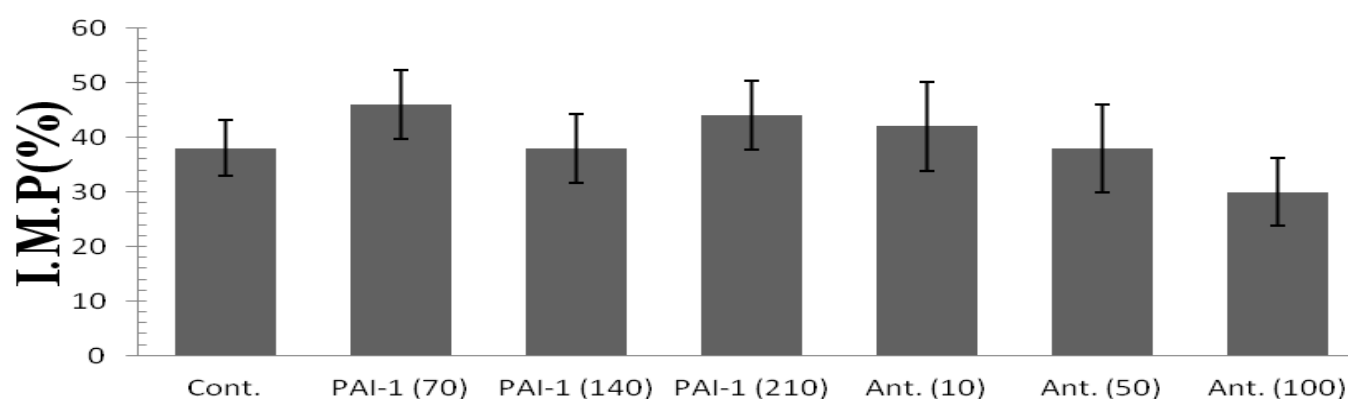

Figure 2. Post-thawing plasmatic membrane integrity (I.M.P) of Curraleiro Pé-Duro bovine semen cryopreserved at different concentrations of serine proteases inhibitors Antipain (10, 50 e 100 $\mu \mathrm{g})$ and inhibitor plasminogen activator 1 - PAI 1 (70, 140 e 210ng). Different letters in the column indicate significant differences $(\mathrm{P}<0.05)$.

Table 2. Post-thawing defects of Curraleiro Pé-Duro bovine semen cryopreserved at different concentrations of serine proteases inhibitors Antipain (10, 50 e 100 $\mu \mathrm{g})$ and inhibitor plasminogen activator 1 - PAI 1 (70, 140 e $210 \mathrm{ng})$

\begin{tabular}{|c|c|c|c|}
\hline \multirow[t]{2}{*}{ Treatment } & \multicolumn{3}{|l|}{ Defects } \\
\hline & $\mathrm{DMa}$ & DMe & DT \\
\hline Control & $6.2 \pm 0.9$ & $17.2 \pm 2.0$ & $23.5 \pm 1.9$ \\
\hline PAI-1 (70) & $7.0 \pm 1.4$ & $12.5 \pm 3.3$ & $19.5 \pm 2.0$ \\
\hline PAI-1 (140) & $8.2 \pm 3.0$ & $15.7 \pm 1.5$ & $24.0 \pm 2.5$ \\
\hline PAI-1 (210) & $6.2 \pm 0.9$ & $13.0 \pm 1.8$ & $19.2 \pm 2.6$ \\
\hline Antipain (10) & $8.2 \pm 1.5$ & $15.5 \pm 4.7$ & $23.7 \pm 6.0$ \\
\hline Antipain (50) & $7.5 \pm 1.7$ & $13.7 \pm 2.6$ & $21.2 \pm 3.5$ \\
\hline Antipain (100) & $8.0 \pm 2.3$ & $16.2 \pm 2.8$ & $24.2 \pm 4.1$ \\
\hline
\end{tabular}

Values are expressed as average \pm standard deviation (SD)

DMa - major defects; DME - minor defects; DT - total defects.

Mean values with different lowercase letters in the same column indicate significant difference $(\mathrm{P}<0.05)$ by SNK test. 
The acrosome integrity of the spermatozoa was influenced by cryopreservation with different concentrations of serine protease inhibitors when compared to their respective control groups (Figure 3). In the presence of Antipain $(10 \mu \mathrm{g}$, $50 \mu \mathrm{g}$ and $100 \mu \mathrm{g}$ ) and PAI- 1 at concentrations of 70 and 140ng, the percentage of spermatozoa with an intact acrosome was higher than in the control $(\mathrm{P}<0.05)$. There was no statistical difference in the acrosome reaction rate (Figure 4) of the treatments compared to the control. When the treatments were compared, PAI-1 (70), PAI-1 (140), PAI-1 (210) and Ant. (10) had a higher acrosome reaction rate compared to 100 $\mu \mathrm{g}$ Antipain $(\mathrm{P}<0.05)$.

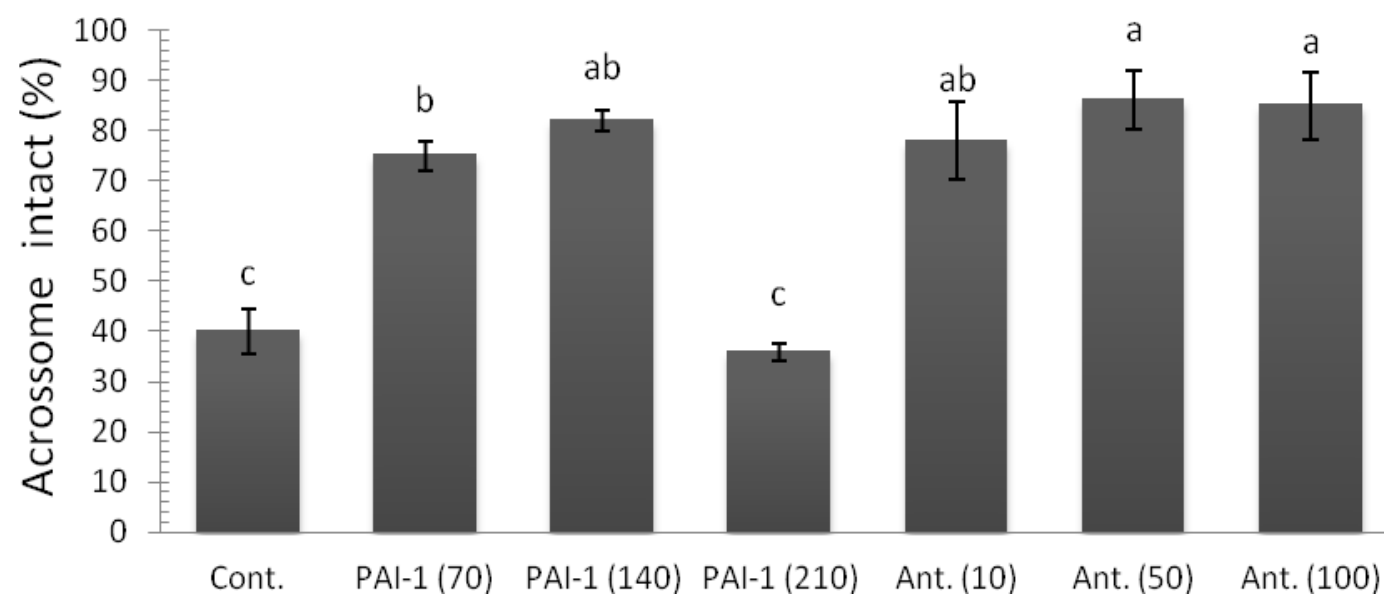

Figure 3. Post-thawing acrosome integrity of Curraleiro Pé-Duro bovine semen cryopreserved at

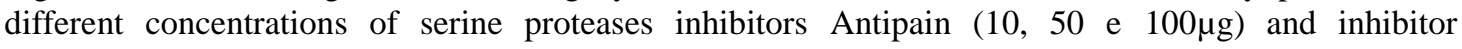
plasminogen activator 1 - PAI 1 (70, 140 e 210ng). Different letters in the column indicate significant differences $(\mathrm{P}<0.05)$.

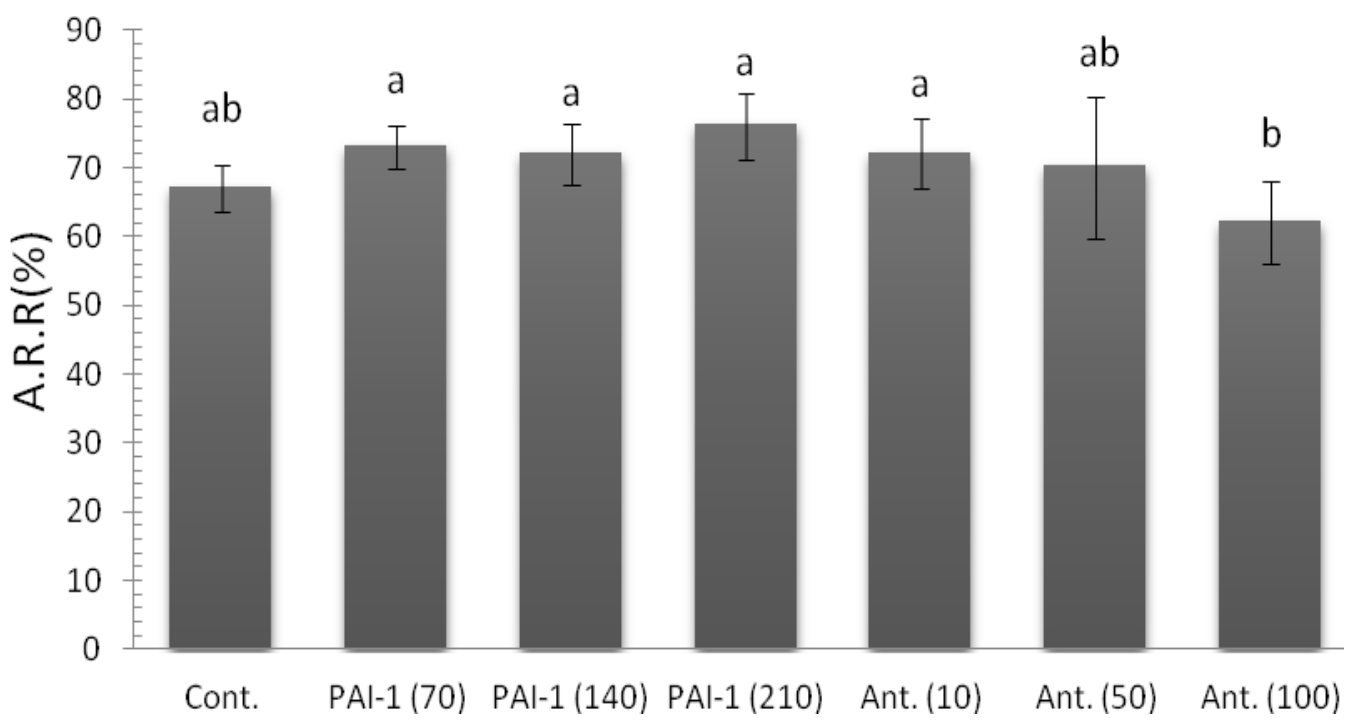

Figure 4. Post-thawing acrosome reaction rate (A.R.R) of Curraleiro Pé-Duro bovine semen cryopreserved at different concentrations of serine proteases inhibitors Antipain (10, 50 e $100 \mu \mathrm{g})$ and inhibitor plasminogen activator 1 - PAI 1 (70, 140 e 210ng). Different letters in the column indicate significant differences $(\mathrm{P}<0.05)$. 


\section{DISCUSSION AND CONCLUSION}

When the sperm were cryopreserved under Antipain, the parameters MP, VSL, LIN, SRT and Hyperactivity were affected $(\mathrm{P}<0.05)$ when compared to control. Spermatozoa cryopreserved in the presence of PAI-1 had the kinetic parameters VSL and LIN affected only when used at a210ng concentration, the other concentrations did not influence the kinetic parameters. Of the two inhibitors tested in this study, Antipain had a more pronounced negative effect $(\mathrm{P}<0.05)$ on sperm kinetic parameters. Lamirande and Gagnon (1986) evaluated the effect of many serine protease inhibitors on human, mouse and bovine sperm motility. They used concentrations of 2000-2250 $\mu \mathrm{M}$ but observed no inhibitory effect on sperm motility. In other studies, rabbit sperm remained with unchanged motility for 8 hours when in presence of $200 \mu \mathrm{M}$ serine inhibitor tosyl protease lysyl chloromethyl ketone (TLCK) (Zaneveld et al., 1970) whereas hamster sperm motility decreased after 15 minutes of incubation at concentrations above $135 \mathrm{mM}$ TLCK (Miyamoto and Chang, 1973). The hyperactivated sperm percentage was lower $(\mathrm{P}<0.05)$ when they were cryopreserved in the presence of Antipain. Considering that hyperactivation is one of the main markers of sperm capacitation, it shows that antipain has a protective effect reducing the cryocapacited spermatozoa.

Despite the serine protease inhibitors (PAI-1 and Antipain) having influenced the motility, they did not show $(\mathrm{P}>0.05)$ any change on the plasmic membrane, mitochondrial function and sperm defects when compared to control. These inhibitors may not have acted on the mechanisms responsible for controlling bovine sperm physical integrity, because serine protease inhibitors act in various enzymatic systems present in the membrane, ranging from blocking the inactivation of the adenylate cyclase activity, as observed in pig spermatozoa (Okamura et al., $1990)$ to the acrosome reaction in mouse spermatozoa (Fraser, 1982; Lai et al., 1991). Serine protease Inhibitors are present in the mammalian reproductive tract (Fritz et al., 1976; Meloun et al., 1983), and are important for protease activities balance and consequently for the protection of the genital tract epithelium against damage by proteolysis (Tschesche et al., 1982). Furthermore, they provide a physiological function, regulating the fertilization process (Cechova' and Jona'kova', 1981; Huhtala, 1984). Thus, the present study showed that serine protease inhibitors are able to influence the quality of cryopreserved sperm.

The acrosome reaction after thawing was not altered in the presence of Antipain and PAI-1 in the control. Previous studies have shown the negative interference of serine protease inhibitors over the acrosome reaction during in vitro fertilization of rats (Honda et al., 2002) humans (De Jonge et al., 1989) and bovines (Deppe et al., 2008), which was not evident in this study. Furthermore, both Antipain and PAI-1 have shown a protective effect on acrosome integrity except in PAI-1 at $210 \mathrm{ng}$ concentration. The improvement in acrosome integrity of sperm cryopreserved with Antipain and PAI-1 can be attributed to the inhibitory effect of trypsin on adenylate cyclase, starting the mechanisms involved with sperm capacitation (Okamura et al., 1990). The spermatozoa that undergo acrosome reaction are able to penetrate the zona pellucida (ZP); acrosome exocytosis of its content is a prerequisite for successful fertilization (Yanagimachi, 1994). Therefore, it is important to consider the fact that Antipain and PAI-1 protected the acrosome and were unable to inhibit the acrosome reaction, being ideal for use in the in vitro fertilization process in bovines. In human sperm, when acrosome reaction was induced by progesterone in the presence of synthetic inhibitors of serine protease the acrosome reaction did not occur (Pillai and Meizel, 1991). In contrast, there was inhibition of blistering with loss of acrosome matrix after induction with calcium ionophore. Similar results were reported on mice sperm (Fraser, 1982) and mouse sperm (Meizel and Lui, 1976). On the other hand, in guinea pig sperm (Cavia porcellus) it was observed that the synthetic serine protease inhibitor ( $\mathrm{p}$-aminobenzamidine) did not block the membrane vesiculation but the acrosome matrix dispersion (Green et al., 1994).

In conclusion, supplementation with the serine protease inhibitors, Antipain and plasminogen activator inhibitor 1 (PAI-1), in bovine semen cryopreservation, preserves the acrosome integrity, without affecting the acrosome reaction in in vitro post thawing. The use of serine protease inhibitors may be beneficial to prevent premature sperm capacitation, avoiding 
subfertility in frozen semen, so it could be used in future experiments to elucidate specific serine protease roles during fertilization.

\section{ACKNOWLEDGEMENTS}

The authors thank Prof Maria Madalena Pessoa Guerra, the College of Veterinary Medicine at the Federal Rural University of Pernambuco, Recife, Brazil, for help in the flow cytometric analysis and computer-assisted semen assessment - CASA. The authors would like to thank the Brazilian Enterprise for Agricultural Research - Empresa Brasileira de Pesquisa Agropecuária - EMBRAPA MEIO NORTE, Teresina, Piauí, Brazil, for providing the research animals.

\section{REFERENCES}

ADHAM, I.; NAYERNIA, K.; ENZEL, W. Spermatozoa lacking acrosin protein show delayed fertilization. Mol. Reprod. Dev., v.46, p.370-376, 1997.

BEYNON, R.J.; BOND, J.S. Proteolytic enzymes: a practical approach. 2.ed. New York: Oxford University Press, 2001. 360p.

BLOOM, E. Ultrastructure of some characteristic sperm defects and a proposal for a new classification of the bull spermiogram. Nord. Vet. Med., v.25, p.383-391, 1973.

BURKART, A.D.; XIONG, B.; BAIBAKOV, B. et al. Ovastacin, a cortical granule protease, cleaves ZP2 in the zona pellucid to prevent polyspermy. J. Cell. Biol., v.197, p.37-44, 2012.

CBRA. Colégio Brasileiro de Reprodução Animal (2013). 'Manual para exame andrológico e avaliação de sêmen animal'. (CBRA: Belo Horizonte)

CECHOVA', D.; JONA'KOVA', V. Bull seminal plasma proteinase inhibitors. Methods Enzymol., v.80, p.792-803, 1981.

CESARI, A.; MONCLUS, M.A.; TEJÓN, G.P. et al. Regulated serine proteinase lytic system on mammalian sperm surface: there must be a role. Theriogenology, v.74, p.699-711, 2010.

COLETO, Z.F.; GUERRA, M.M.P.; BATISTA, A.M. Avaliação do sêmen congelado de caprinos com drogas fluorescentes. Rev. Bras. Med. Vet., v.24, p.101-104, 2002.
COY, P.; JIMÉNEZ-MOVILLA, M.; GARCÍAVÁZQUEZ, F.A. et al. Oocytes use the plasminogen-plasmin system to remove supernumerary spermatozoa. Hum. Reprod., v.27, p.1985-1993, 2012.

DE JONGE, C.J.; MACK, S.R.; ZANEVELD, L.J. Inhibition of the human sperm acrosome reaction by proteinase inhibitors. Gamete Res., v.23, p.387-397, 1989.

DEPPE, M.; MORALES, P.; SANCHEZ, R. Effect of protease inhibitors on the acrosome reaction and sperm-zona pellucida binding in bovine sperm. Reprod. Domest. Anim., v.43, p.713-719, 2008

FRASER, L.R. p-Aminobenzamidine, an acrosin inhibitor, inhibits mouse sperm penetration of the zona pellucida but not the acrosome reaction. $J$. Reprod. Fert., v.65, p.185-194, 1982.

FRITZ, H.; TSCHESCHE, H.; FINK, E. Proteinase inhibitors from boar seminal plasma. Methods Enzymol., v.45, p.834-847, 1976.

GREEN, C.E.; WATSON, P.F. Comparison of the capacitation-like state of cooled boar spermatozoa with true capacitation. Reproduction, v.122, p.889-898, 2001.

GREEN, G.R.; BALHORN, R.; POCCIA, D.L.; HECHT, N.B. Synthesis and processing of mammalian protamines and transition proteins. Mol. Reprod. Dev., v.37, p.255-263, 1994.

GURUPRIYA, V.S.; DIVYASHREE, B.C.; ROY, S.C. Cryogenic changes in proteases and antiprotease activities of buffalo (Bubalus bubalis) and cattle (Bos taurus) sêmen. Theriogenology, v.81, p.396-402, 2014.

GUTHRIE, H.D.; WELCH, G.R. Determination of intracellular reactive oxygen species and high mitochondrial membrane potential in Percolltreated viable boar sperm using fluorescenceactivated flow cytometry. J. Anim. Sci., v.84, p.2089-2100, 2006.

HONDA, A.; YAMAGATA, K.; SUGIURA, S. et. al. A mouse serine protease TESP5 is selectively included into lipid rafts of sperm membrane presumably as a glycosylphosphatidylinositolanchored protein. $J$. Biol. Chem., v.277, p.16976-16984, 2002. 
HUHTALA, M.L. Demonstration of a new acrosin inhibitor in human seminal plasma. Hoppe-Seyler's. Z. Physiol. Chem., v.365, p.819$825,1984$.

IWAMOTO, K.; IKEDA, K.; YONEZAWA, N. et al. Disulfide formation in bovine zona pellucida glycoproteins during fertilization: evidence for the involvement of cystine crosslinkages in hardening of the zona pellucida. J. Reprod. Fertil., v.117, p.395-402, 1999.

KUMAR, R.; ATREJA, S.K. Effect of incorporation of additives in tris-based egg yolk extender on buffalo (Bubalus bubalis) sperm tyrosine phosphorylation during cryopreservation. Reprod. Domest. Anim., v.47, p.485-490, 2011.

LAI, M.L.; CHEN, S.W.; CHEN, Y.H. Purification and characterization of trypsin inhibitors from mouse seminal vesicle secretion. Arch. Biochem. Biophys., v.290, p.265-271, 1991.

LAMIRANDE, E.; GAGNON, C. Effects of protease inhibitors and substrates on motility of mammalian spermatozoa. J. Cell. Biol., v.102, p.1378-1383, 1986.

MEIZEL, S.; LUI, C.W. Evidence for the role of a trypsin-like enzyme in the hamster sperm acrosome reaction. J. Exp. Zool., v.195, p.137144, 1976.

MELOUN, B.; CECHOVA', D.; JONA'KOVA', $\mathrm{V}$. Homologies in the structures of bull seminal plasma acrosin inhibitors and comparison with other homologous proteinase inhibitors of the Kazal type. Hoppe-Seyler's. Z. Physiol. Chem., v.364, p.1665-1670, 1983.

MIAH, A.G.; SALMA, U.; SINHA, P.B. et al. Intracellular signaling cascades induced by relaxin in the stimulation of capacitation and acrosome reaction in fresh and frozenthawed bovine spermatozoa. Anim. Reprod. Sci., v.125, p.30-41, 2011.

MIYAMOTO, H.; CHANG, M.C. Effects of protease inhibitors on the fertilizing capacity of hamster spermatozoa. Biol. Reprod., v.9, p.533$537,1973$.
MONDÉJAR, I.; GRULLÓN.; L.A.; GARCÍAVÁZQUEZ F.A. et al. Fertilization outcome could be regulated by binding of oviductal plasminogen to oocytes and by releasing of plasminogen activators during interplay between gametes. Fertil. Steril., v.97, p.453-461, 2012.

MURASE, T.; MUKOHJIMA, K.; SAKAGUCHI S. et al. Characterization of frozen-thawed Japanese black bull spermatozoa by standard semen analysis, muçus penetration test and the ability to undergo the acrosome reaction in response to calcium and the calcium ionophore A23187. J. Reprod. Dev., v.47, p.237-243, 2001.

NAR, H.; BAUER, M.; STASSEN, J.M. et al. Plasminogen activator inhibitor-1. Structure of the native serpin, comparison to its other conformers and implications for serpin inactivation. J. Mol. Biol., v.297, p.683-695, 2000 .

OKAMURA, N.; ONOE, S.; KAWAKURA, K. et al. Effects of a membrane bound trypsin-like proteinase and seminal proteinase inhibitors on the bicarbonate-sensitive adenylate cyclase in porcine sperm plasma membranes. Biochim. Biophys. Acta, v.1035, p.83-89, 1990.

PILLAI, M.C.; MEIZEL, S. Trypsin inhibitors prevent the progesterone-initiated increase in intracellular calcium required for the human sperm acrosome reaction. J. Exp. Zool., v.25, p.384-393, 1991

POMMER, A.; MEYERS, S. Tyrosine phosphorylation is an indicator of capacitation status in fresh and cryopreserved stallion spermatozoa. Theriogenology, v.58, p.351-355, 2002.

PRIMAKOFF, P.; MYLES, D.G. Penetration, adhesion, and fusion in mammalian sperm-egg interaction. Science, v.296, p.2183-2185, 2002.

REDDY, N.S.S.; JAGAN, M.G.; ATREJA, S.K. Effects of adding taurine and trehalose to a trisbased egg yolk extender on buffalo (Bubalus bubalis) sperm quality following cryopreservation. Anim. Reprod. Sci., v.119, p.183-190, 2010.

REKKAS, C.A.; BESENFELDER, U.; HAVLICEK, V. et al. Plasminogen activator activity in cortical granules of bovine oocytes during in vitro maturation. Theriogenology, v.57, p.1897-1905, 2002. 
ROTH, T.L.; WEISS, R.B.; BUFF, J.L. Heterologous in vitro fertilization and sperm capacitation in an endangered African antelope, the Scimitar-Horned Oryx (Oryx dammah). Biol. Reprod., v.58, p.475-482, 1998.

SAWADA, H.; YOKOSAWA.; H.; SOMENO T. et al. Evidence for the participation of two sperm proteases, spermosin and acrosin, in fertilization of the ascidian, Halocynthia roretzi: inhibitory effects of leupeptin analogs on enzyme activities and fertilization. Dev. Biol., v.105, p.246-249, 1984.

SHIMADA, M.; NISHIBORI, M.; YAMASHITA, Y. et. al. Down-regulated expression of A disintegrin and metalloproteinase with thrombospondin-like repeats-1 by progesterone receptor antagonist is associated with impaired expansion of porcine cumulus-oocyte complexes. Endocrinology, v.45, p.4603-4614, 2004.

SINGH, V.K.; ATREJA, S.K.; KUMAR, R. et al. Assessment of intracellular $\mathrm{Ca} 2+$, cAMP and 1,2-diacylglycerol in cryopreserved buffalo (Bubalus bubalis) spermatozoa on supplementation of taurine and trehalose in the extender. Reprod. Domest. Anim., v.47, p.584590, 2012.

STATISTICAL analysis system. Version 9.2. Cary: SAS Institute, 2013.
THOMAS, A.D.; MEYERS, S.A.; BALL, B.A. Capacitation-like changes in equine spermatozoa following cryopreservation. Theriogenology, v.65, p.1531-1550, 2006.

TSCHESCHE, H.; WITTIG, B.; DECKER, G. et al. A new acrosin inhibitor from boar spermatozoa. Eur. J. Biochem., v.126, p.99-104, 1982.

TULSIANI, D.R.; ABOU-HAILA, A.; LOESER, C.R.; PEREIRA, B.M. The biological and functional significance of the sperm acrosome and acrosomal enzymes in mammalian fertilization. Exp. Cell. Res., v.240, p.151-164, 1998.

UMEZAWA, S.; TATSUTA, K.; FUJIMOTO, K. et al. Structure of antipain, a new Sakaguchipositive product of streptomyces. J. Antibiot., v.25, p.267-270, 1972.

WATSON, P.F. The causes of reduced fertility with cryopreserved semen. Anim. Reprod. Sci., v.60, p.481-492, 2000.

YANAGIMACHI, R. Mammalian fertilization. In: KNOBIL, E.; NEILL, J.D. The physiology of reproduction, 3.ed. New York: Raven Press, 1994. p.189-317

ZANEVELD, L.J.D.; ROBERTSON, R.T.; WILLIAMS, W.L. Synthetic enzyme inhibitors as antifertility agents. FEBS Lett., v.11, p.345$347,1970$. 